\title{
Olena Davlikanova,
}

Project Coordinator, Friedrich Ebert Foundation, Office in Ukraine, Ukraine

ORCID ID, 0000-0001-8536-3959,

email: elena100deals@gmail.com

Helmut Hofstetter,

Professor, Berlin School of Economics \& Law, Germany

ORCID ID, 0000-0002-7263-2520

email: helmut.hofstetter@hwr-berlin.de

Correspondence author: elena100deals@gmail.com

\section{THE «DUALES STUDIUM» ADAPTATION AS AN INNOVATION IN UKRAINIAN TERTIARY EDUCATION: MANAGEMENT ASPECTS AND RESULTS}

Abstract. The fourth industrial revolution and integration of the human capital concept into policymaking attract more attention to the ways of shortening the gap between the demands of the laborr market and the «supply» of educational establishments. One of the ways to approach ensuring the efficient response is to export and adapt the «made in Germany» dual education/studies models, especially in tertiary education. Ukraine had had no similar systemic approach before the launch of a project on the importing of the dual higher education or dual studies («Duales Studium», DS) by the Friedrich-Ebert-Stiftung Office in Ukraine in 2013 (FES-Ukraine). The article aims to present state of the art with the «import» of the Duales Studium as of 2020 and main findings of the author's questionnaire survey on the results of the first year of the national experiment in Ukrainian higher educational establishments (HEEs) under the supervision of the Ministry of Education and Science of Ukraine (MES). The author's questionnaire survey was carried out from February to August 2020. The respondents included 27 higher educational establishments listed in the ministerial Order №1296 on the launch of the national wide dual studies experiment to be conducted in 20192023. The answers were obtained from the 23 HEEs, though not all of the answers were valid. The data obtained allowed to do both quantitative and qualitative analysis. The findings show that principles of the dual studies may be successfully adapted and implemented in the Ukrainian tertiary education, despite the lack of many components of German dual system, as well as some misinterpretations or purposeful misuse of the suggested mechanisms on the ground. Ukrainian dual studies may not be called a «dual system» yet, as many elements are still lacking and some cannot be re-created in the national context, but it is a form of studies that may already now be chosen by a student, as is demonstrated by 60 cases implemented by 17 HEEs on the examples of 31 majors and 441 students, out of which 123 are female and 318 male. Therefore, the obtained experience is a source of valuable information for recommendations to the stakeholders (educational institutions, employers and their associations, students, ministries, the Government and local self-government bodies etc.) aimed at boosting their further cooperation. Thus, it creates favourable conditions for training a capable workforce, which is one of the factors of compatibility and growth of both individual economic actors and the national economy as a whole. The authors' contributions are as follows: elaboration of the draft questionnaire, description of the methodology, data analysis of the first year of the dual studies introduction by Ukrainian HEEs, conclusions and recommendations (Olena Davlikanova); input on experience of Dual Studies organization in Germany from the perspective of companies and HEEs (Prof. Helmut Hofstetter).

Keywords: dual higher education, dual form of education, dual studies, dual study models, dual tertiary education, Duales Studium, employers, higher educational institutions, human capital, Ministry of Education and Science of Ukraine, pilot project, students, tertiary education.

Introduction. Concerning the fast technological development and the arising knowledge economy, it is essential, especially for the developing economies like the Ukrainian one, to ensure a favorable environment for meeting the need of the economy in the workforce with both complex practical

Cite as: Davlikanova, O., \& Hofstetter, H. (2020). The «Duales Studium» Adaptation as an Innovation in Ukrainian Tertiary Education: Management Aspects and Results. Marketing and Management of Innovations, 3, 208-221. http://doi.org/10.21272/mmi.2020.3-15 
O., Davlikanova, H., Hofstetter. The «Duales Studium» Adaptation as an Innovation in Ukrainian Tertiary Education: Management Aspects and Results

competencies and solid theoretical knowledge. Listing the factors ensuring its strong economy and low unemployment rate, the Federal Republic of Germany mentions dual education (mainly dual vocational education and training - «Duale Ausbildung»). Its principles in recent decades are being integrated into tertiary education as dual studies («Duales Studium»). Though, the concept and criteria of the dual studies are still being discussed on its motherland (BiBB, 2017), it is already possible to «export» its philosophy and best practices for further adaptation to the national contexts. Thus, in 2013 Friedrich Ebert Foundation Office in Ukraine in cooperation with local partners started a project «Adaptation of Dual Studies Elements to the Ukrainian National Context». The circle of project partners has been growing ever since, and now it includes the Ministry of Education and Science of Ukraine, 27 HEEs both state and private, an NGO «Ukrainian Marketing Association», the Federation of Employers of Ukraine, the Federation of Metallurgists of Ukraine, big, middle and small businesses, the Methodological Center for Pre-Tertiary and Tertiary Education and others. As a result of joint activities, the concept on the Dual Form of Education/Studies was developed, at first, for the pre-tertiary and tertiary education. Still, at the final stage, it was decided by the MES to adopt it as a unification document of a declarative character suitable for vocational education and training as well. After the adoption of the concept by the Cabinet of Ministers of Ukraine in 2018 and necessary legislative changes to the Laws «On Education» and "On Higher Education», in 2019 the MES launched an experiment on the introduction of the dual form of education having chosen 17 pre-higher (colleges) and 27 higher educational establishments (Universities, academies) listed in the Order № 1296 as of October 15, 2019. The article aims to present the main findings of the author's questionnaire survey among HEEs (only) on the results of the first year of dual studies experiment. Tertiary education is prioritized to the pre-tertiary due to the growing demand for staff with tertiary education. European Commission recommends minimizing the gap between the content of education and competencies required on the modern labour market expecting half of the jobs on the European labour market to demand higher education by 2025 (European Semester, 2016). The article includes four parts. The first part - literature review - presents conclusions of earlier studies dedicated to the human capital concept, the importance of education and cooperation of educational establishments with business as prerequisites of economic development of countries, with the focus on the recent shift to tertiary education due to the arising knowledge economy, as well as publications devoted to peculiarities of the dual studies organization in Germany and its adoption overseas. The second part - methodology and research methods - outlines methods of the author's questionnaire survey conducted on the request of the Ministry of Education and Science of Ukraine. The third part - results and discussion - summarizes the main findings of the author's questionnaire survey on the first year of dual studies experience in the volunteering and approved by the MES higher educational establishments in comparison to the approaches applied in the country of dual studies origin. The fourth part - conclusions - presents implications for the continuation of the experiment of the Ministry of Education and Science of Ukraine, development of national normative framework and suggestions for widening the scope of dual study proposals in Ukraine.

Literature Review. Knowledge is the base of any economic system (Toffler, 1990). The long-term economic development depends on the knowledge that is the cornerstone of innovations as the source of economic growth (Romer, 1990). The technological development of the past decades rooted in the emergence of modern science is unprecedented, which brings in the question of the encompassing costs on education as a capital investment into national accounting framework (Kuznetz, 1971). Knowledgebased economy characterizes the post-industrial world, where the main factor of progress is knowledge rooted in human capital (Ivanova, 2011). In contrast to explicit knowledge, which helps us «know what», tacit knowledge, the «know-how» is something that we often can't learn by hearing lectures or reading books. It is acquired by addressing real problems and practice and relates to experience, ideas, intuition, values, creative thinking, emotions, skills and attitudes (Sternberg, 1999). 
O., Davlikanova, H., Hofstetter. The «Duales Studium» Adaptation as an Innovation in Ukrainian Tertiary Education: Management Aspects and Results.

Education is a source of capital (Schultz, 1960), which, in combination with skills, plays an essential role in promoting social progress. It is one of the factors of personal well-being, especially in the context of the economic crisis and growing economic inequality, where youth, as well as uneducated and lowskilled adults, are the most vulnerable groups on the labour market (Education at a Glance, 2014). In the context of deepening socio-economic inequality in the world, the correlation between a person's level of education and skills and hislher life opportunities has significantly increased. Thus, the EU has identified one of the goals in education to achieve a share of $40 \%$ of the population aged 30-34 with higher education (Education and Training, 2020). The share of the Ukrainian population over the age of 25 with higher and incomplete higher education exceeds 40\% (World Bank, 2019). However, both the national innovation rate and the results of a nationwide survey «Higher Education in Ukraine: Public Opinion of Students» demonstrate its low quality - at the level of 2.8 points on a 5-point scale (The Ilko Kucheriv Democratic Initiatives Foundation, 2015). Among the most critical factors undermining the effectiveness of the domestic formal education and training system is the lack of focus on graduates' qualifications required by the employers, poor management and insufficient funding (World Bank, 2017). Given the current situation, the Strategy for Reforming Higher Education in Ukraine until 2020 among the main objectives of the reform provided for the following: (Objective 2) reorganization of the higher education management system and involvement of the public, professional associations in decision-making; (Objective 3) transformation of universities into the centres of independent thought, capable of training professionals and generating ideas for accelerated modernization of the country; (Objective 5) work-based training, dual education/studies (the MES, 2015). The experiments on the adaptation of the German experience of dual education/studies adaptation were implemented in several countries around the world. It allows creating a proper link between the real economy and the higher education system and ensuring appropriate investments into human capital that assist in boosting innovations and economic growth. This «export» typically falls under very different starting conditions: most of the countries don't have a master-apprentice history, but most of them have a kind of education for professionals like technical schools or polytechnical HEE. The main challenges lie in the poor quality and deficient cooperation with companies, and, most notably, low prestige of professional education (Graf et al., 2014). Suppose dual VET («Duale Ausbildung») is a well-established model in the Federal Republic of Germany. In that case, a whole variety of dual studies («Duales Studium») models exist, and the discussion on the main DS criteria is ongoing (BiBB, 2017). The ways and forms of cooperation between the parties vary greatly along with types of dual programs, agreements with employers or specific regulations adopted in the federal lands (Braun, 2018). Thus, it is important to avoid a «copy-paste» strategy and look for the best ways of adaptation of the DS philosophy to the national context, including, legislation framework, socio-economic conditions and (lack of) traditions of stakeholders' dialogue as of participation in education.

Methodology and research methods. For safeguarding relevance of the article to the demands of the national economy and market of education services, cabinet study of earlier works on the interdependence of the economic growth, innovations, human capital and education, especially dual studies, has been conducted starting 2013. Thus, dual studies have become the focus of the study as a mechanism that allows ensuring the combination of profound theoretical knowledge and relevant practical experience acquired by the workforce. In contrast, German best practices have been explored through study trips, interviews of German DS stakeholders, in the framework of international conferences, as well as preparation of methodological materials for Ukrainian stakeholders. The acquired information has become the ground for formatting normative basis and launch the national experiment by the Ministry of Education and Science of Ukraine. As a result, a questionnaire for higher educational establishments listed in the Order №1296 on Dual Studies Experiment issued by the Ministry of Education and Science of Ukraine was developed by the author in February 2020 and presented for a review of an expert group made of the representatives of education and business. The questionnaire consists of two groups of 
O., Davlikanova, H., Hofstetter. The «Duales Studium» Adaptation as an Innovation in Ukrainian Tertiary Education: Management Aspects and Results

questions. The first is on steps taken by the HEEs to introduce the dual form of studies (stage of the DS introduction). The second is on particular cases by majors, which represent exact organizational and methodological approaches applied to ensure the cooperation of an HEE and a company to train a student under a particular major (stage of the DS implementation). Out of the 44 questions, 17 are multiple-choice, 15 are open, and 12 require submission of comments or particular documents. For instance, it could be the HEE's orders on the introduction of the dual form of education, the appointment of the responsible persons, two-party agreements with companies, three-party agreements between an HEE, a company and a student, curriculum and individual study plan etc. In April 2020, the Methodological Center for pretertiary and tertiary education spread the questionnaire as a Google-form among the educational establishments listed in the Order №1296. Thus, the methods applied are the universal coverage, casestudy and sampling. The universal coverage was chosen due to the fact that the overall sample is relatively small - 27 HEEs indicated in the MES Order №1296. It also allowed using the case-study method to gather more detailed information on the experience of the indicated educational establishments. Due to several factors, including the quarantine, some HEEs submitted information only regarding the introduction stage with no available cases of implementation; or submitted cases which do not qualify as dual studies. Thus, the sampling method was also applied. The formulas were applied as follows:

$$
\begin{aligned}
& \text { S1 }=\text { Ta-Rn-Ri (where } T a=T \text { ) } \\
& \text { S2 }=\text { Rc-Ric }
\end{aligned}
$$

where S1 - sample of HEEs for the DS introduction stage; Ta - total number of HEEs approached; $\mathrm{T}$ - total number of HEEs in the experiment; $\mathrm{Rn}$ - non-responses (by HEEs); Ri - invalid responses (by HEEs); S2 - sample of cases for the DS introduction stage; Rc - responses (by cases); Ric - invalid responses (by cases).

Several constraints factors had to be taken into account when identifying criteria for assessing the results of the first year of the experiment on shaping national approaches to dual studies' organization:

1) dual education is defined as a form of studies (as an alternative to day studies). It requires the adoption of internal documentation and procedures at HEEs to enable students to apply for it, as the admission to HEEs is strictly regulated by the External Independent Evaluation/Testing (EIE). EIE is unified for all applicants procedure of acceptance to HEEs developed as part of anti-corruption measures. Still, as a selection of dual students by a company is essential and should be ensured, it is foreseen after the admission to the HEE;

2) at this stage, Ukraine needs to acquire maximum possible cases from different majors, and qualification levels and some employers are eager to accept students only on the third academic year of bachelor's programs or those at master's programs. Thus, MES allowed the transfer of students to the dual form of education at any academic year. It had complicated the count of the percentage of practice component (or ECTS credits), which is most relevant for cases when students started the dual program right after the admission.

The criteria to qualify the inclusion into the Sample 1 based upon the Provision on the Organization Studies under the Dual Form elaborated by a working group under the MES and FES-Ukraine's supervision, which was offered for a public discussion and is to be finalized after the experiment as part of normative basis: 1) issued by an HEE internal order on the DS introduction and elaborated procedure of transfer of day students to the dual form of studies; 2) appointment of responsible persons or establishment of a special DS unit in HEE; 3) signed bilateral agreements between the HEE and a partnercompany/ies. The criteria to qualify a case as an example of the dual form of studies within Sample 2 draw upon the definition provided in the Law «On Higher Education». In this case, «The dual form of tertiary education is a way of getting education by daytime students acquiring a certain qualification that involves 
O., Davlikanova, H., Hofstetter. The «Duales Studium» Adaptation as an Innovation in Ukrainian Tertiary Education: Management Aspects and Results.

work-based learning (apprenticeship) in enterprises, institutions and organizations that amounts to 25-60 per cent of the total educational program and foresees conclusion of a contract. Work-based learning (apprenticeship) involves the performance of official duties following the employment contract» (The Law of Ukraine on Higher Education, 2019). DS also foresees ensuring the thematic combination of theory and practice components. Thus, the following formal requirements have been identified by the researcher: 1). signed trilateral agreements between the HEE, a partner-company and a student; 2). work contract offered by a partner company and signed by a student; 3) formed individual study plans with the interrelated content of theory and practice components, as well as the established timeframe for academic and onthe-job training phases. It should be noted that there are no elaborated means of external assessment of the relevance of theory and practice components yet. Thus, it relied on the self-assessment of the respondents. Meeting 2 out of 3 criteria for each sample qualified data for inclusion into the report. Only HEEs qualified for Sample 1 could qualify for Sample 2.

The answers were provided by persons responsible for dual studies in HEEs. The data gathering was accomplished in June 2020. The author analyzed the results of the first year of the dual studies introduction in Ukrainian HEEs, while the Methodological centre analyzed data submitted by the pre-tertiary educational establishments separately. Thus, the latter is not included in this article. The information processing included both quantitative and qualitative analysis. For reaching the aim of the survey, the following four hypotheses concerning the peculiarities of dual studies have been tested: 1) dual studies are applicable to the national context but require flexibility in its adaptation; 2) despite the need in clear "rules of the game", diversity of majors will not allow to strictly formalize DS; 3) such factors as the introduction of the DS top-bottom, lack of tradition of employer-HEE cooperation and unstable economic and political situation will require relying on educational institutions as promoters of DS, and 4) practiceintegrated model will be the most demanded DS model.

Results. The non-response rate is 0,14 ; the valid response rate for the first group of questions is 0,74 , and for the second group of questions - 0,69. Out of the 27 HEEs listed in the Ministerial Order №1296, the responses to the questionnaire were provided by 23 HEEs. In turn, three of them were invalid. Herewith, two HEEs submitted partial reports not included in the analysis due to the lack of key data; one HEE stated that the partner-company was by mistake indicated in the order, as it was located on the currently occupied territory on the East of Ukraine). Besides, 3 HEEs claimed that due to the COVID-19 quarantine measures, the DS implementation is postponed for 2020-2021 academic year. However, the preparatory work was done (HEE internal documentation prepared, responsible persons appointed, selection criteria for partner companies elaborated, and even bilateral agreements with employers concluded). Thus, the analysis included data from 20 HEEs that introduced DS in 2019-2020 a.y. for the first group of questions. Herewith, it included $17 \mathrm{HEEs}$ that could present real cases for the second group of questions, which made 60 cases ( 1 case $=1$ major in $1 \mathrm{HEE}$ ) in total for 31 majors, 441 students (123 female and 318 male students) (Table 1).

Table 1. Samples for the first (the DS introduction stage) and second (the DS implementation stage) groups of questions in the questioner regarding the results of the first year of the dual studies experiment in Ukraine.

\begin{tabular}{|l|l|l|}
\hline Values for the Formulas & Sample 1 & Sample 2 \\
\hline Total number of HEEs in the experiment (T) & $27^{*}$ & \\
\hline Total number of HEEs approached (Ta) & 27 & \\
\hline Non-response rate (by HEEs) (Rn) & 4 & 86 \\
\hline Response rate (by cases) (Rc) & & 26 (Ric) \\
\hline Invalid responses & 3 (Ri) & \\
\hline
\end{tabular}

Source: developed by the authors. 
O., Davlikanova, H., Hofstetter. The «Duales Studium» Adaptation as an Innovation in Ukrainian Tertiary Education: Management Aspects and Results

As a result, in Sample 1 is made of 20 HEEs: 1) 17 HEEs issued internal order on the DS launch, 2 have not provided the information; 1 has not signed it yet; 2) 5 established special DS unites, others appointed responsible persons; 3 ) $20 \mathrm{HEEs}$ signed bilateral agreements with employer, which created the basis for 60 DS cases. In Sample 2 made of 60 cases: 1) in 55 cases trilateral agreements were signed, 4 - work in progress, 1 - a student refused to sign a tri-lateral contract but signed a work contract; 2 ) in 48 cases work contacts were concluded with all the students; in 11 cases with some of them (in the framework of one major HEE established partnerships with different companies and the pace of cooperation differs). In the first case, it is work in progress, while students stay in the company as interns; 3 ) in $100 \%$ of cases the individual study plans and timing for academic and on-the-job training were formed and agreed with employers.

In $94 \%$ of the cases, fixed-term work contracts were concluded, while in $6 \%$ of the cases they were open-ended. Thus, employers wanted to ensure that students would stay in the companies after graduation. As for the payment, only in one case, it was specifically indicated that the payment was foreseen for both the theory and practice phases. In two cases, it was specifically indicated that payment is made only for the work-based study periods. In other cases, it was indicated as monthly, for the volume of work done or hours. The amount of payment varies from 30 to $100 \%$ of the salary of a qualified employer in this position. On top of that, students, who have high academic performance rates and whose study is funded from the state budget, are also entitled to monthly payments from the state, the stipend. Employers initiated only $6 \%$ of cooperation incidents; $56 \%$ - by HEEs; $25 \%$ - joint effort of HEEs and employers; $13 \%$ - HEEs, employers and students. It supports the research hypotheses on the prominent role of HEEs as promoters of DS on the first period of its development. As for the number of majors, 3 HEEs launched DS experiment for 14, 10 and 8 majors respectively, other $3 \mathrm{HHEs}$ included 4 majors each in the experiment, rest $11 \mathrm{HEEs}$ offered the range of 1 to 3 majors each (see Table 2). The most «popular» majors among dual students are №133 branch mechanical engineering (6 cases), №075 accounting and taxation, №141 electricity and electrical engineering, №184 mining (4 cases each).

Table 2. Comparative analysis of Germany and Ukraine's national contexts with regard to the DS implementation

\begin{tabular}{|c|l|c|c|}
\hline № & \multicolumn{1}{|c|}{ DS System Element } & Germany & Ukraine \\
\hline 1. & The long-term tradition of HEE and employers' cooperation & + & - \\
\hline $\mathbf{2 .}$ & $\begin{array}{l}\text { Proactive stance of employers in education and training of students as } \\
\text { future workforce and readiness to invest in it }\end{array}$ & + & - \\
\hline 3. & $\begin{array}{l}\text { Existence of special vacancies for dual students and databases of DS } \\
\text { proposals by HEE }\end{array}$ & + & - \\
\hline $\mathbf{4 .}$ & $\begin{array}{l}\text { Possibility to apply for acceptance to the HEE for a dual program } \\
\text { specifically }\end{array}$ & + & - \\
\hline $\mathbf{5 .}$ & Possibility to organize DS for groups & + & $+/-$ \\
\hline $\mathbf{6 .}$ & $\begin{array}{l}\text { The active stance of the Chambers of Trade and Commerce in the } \\
\text { verification of qualifications }\end{array}$ & $+/-$ & $+/-$ \\
\hline 7. & Well-developed normative and legal framework & \\
\hline
\end{tabular}

Source: developed by the authors based on BiBB (2020). 


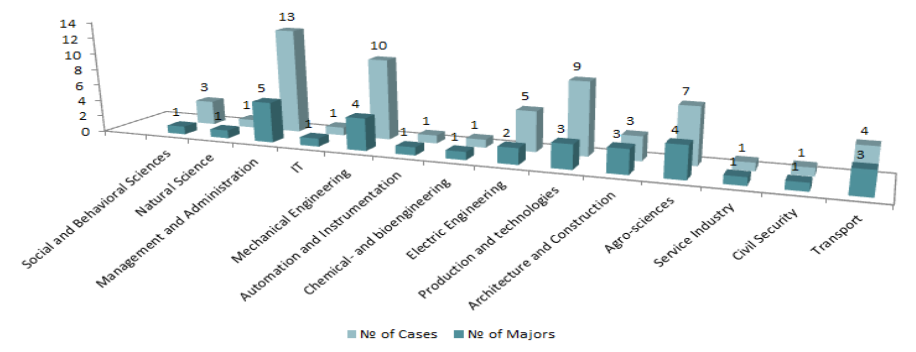

Figure 1. Number of Majors and Cases of DS in 2019-2020 a.y. by the Field of Knowledge Source: developed by the authors.

Due to the strict regulation of the admission procedure to HEEs organized as an External Independent Evaluation, it is impossible to implement original German approaches and launch a separate competition among applicants - potential dual students. In the experiment framework, the transition to the dual form of studies was possible for all students regardless of the studies year. Besides, students of the 3rd year of bachelor's and the 1st year of master's programs were the most required among the employers (Table 3).

Table 3. Overall Process of the Dual Studies Introduction Applied in Ukraine in the First Year of the Experiment on the DS Implementation (2019-2020 a.y.)

\begin{tabular}{|c|c|c|c|c|}
\hline Stage & HEE & Partner-company & Student & Other stakeholders \\
\hline $\begin{array}{l}\text { Stage 0 } \\
\text { (till 2019) }\end{array}$ & \multicolumn{3}{|c|}{ May have heard of DS or introduced elements of DS. } & $\begin{array}{l}\begin{array}{l}\text { FES and partners are } \\
\text { conducting information } \\
\text { campaign and other } \\
\text { activities raising }\end{array} \\
\text { awareness on DS. The } \\
\text { MES in cooperation with } \\
\text { FES and partners create } \\
\text { conditions for DS } \\
\text { experiment by the } \\
\text { elaboration of the } \\
\text { legislative and normative } \\
\text { framework. The MES } \\
\text { issues Order\#1296 }\end{array}$ \\
\hline Stage 1 & $\begin{array}{l}\text { Issues an Order on } \\
\text { the DS introduction } \\
\text { and appoints } \\
\text { responsible persons } \\
\text { or creates a DS unit. } \\
\text { Criteria to partner } \\
\text { companies are } \\
\text { elaborated. }\end{array}$ & 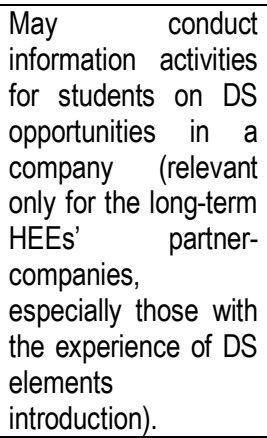 & $\begin{array}{l}\text { Has entered the } \\
\text { HEE based on the } \\
\text { results of the EIE or } \\
\text { is already a student } \\
\text { (self-motivated and } \\
\text { sure about future } \\
\text { career field). }\end{array}$ & $\begin{array}{l}\text { The MES in partnership } \\
\text { with FES-Ukraine and } \\
\text { other actors are providing } \\
\text { recommendations and } \\
\text { support, conduct events } \\
\text { and publish relevant } \\
\text { materials. Profile } \\
\text { employers'associations } \\
\text { may also conduct } \\
\text { information campaigns } \\
\text { among its members on } \\
\text { the benefits of DS. }\end{array}$ \\
\hline
\end{tabular}


O., Davlikanova, H., Hofstetter. The «Duales Studium» Adaptation as an Innovation in Ukrainian Tertiary Education: Management Aspects and Results

Continued Table 3

\begin{tabular}{|c|c|c|c|}
\hline Stage 2 & $\begin{array}{l}\text { The appointed persons contact potentially } \\
\text { interested companies or accept cooperation offers } \\
\text { from them. Relevant majors are chosen. After } \\
\text { negotiations and establishment of the mutual } \\
\text { understanding of the DS essence and } \\
\text { mechanisms, bilateral agreements are concluded. }\end{array}$ & $\begin{array}{l}\text { Are being informed } \\
\text { about DS options by } \\
\text { HEEs or employers. } \\
\text { May suggest } \\
\text { potential partner- } \\
\text { companies. }\end{array}$ & \\
\hline Stage 3 & $\begin{array}{l}\text { Content of the programs is reviewed, and the } \\
\text { selection procedure is being agreed between the } \\
\text { HEE and a partner-company. Criteria to the } \\
\text { students are identified. Criteria to curators at a } \\
\text { workplace are discussed. }\end{array}$ & $\begin{array}{l}\text { Decides to get } \\
\text { transferred to the } \\
\text { dual form of } \\
\text { education. Submits } \\
\text { a request for the } \\
\text { transfer in the HEE } \\
\text { and takes a } \\
\text { testlinterview at a } \\
\text { company. }\end{array}$ & \\
\hline \multirow[t]{4}{*}{ Stage 4} & $\begin{array}{l}\text { Individual plan and schedule, as well as the dual } \\
\text { students' position, are agreed. }\end{array}$ & & \\
\hline & \multicolumn{2}{|l|}{ Trilateral agreements are signed. } & \\
\hline & & $\begin{array}{l}\text { Payments (wage) and other conditions are } \\
\text { negotiated. Contracts between a company and } \\
\text { a student are concluded. }\end{array}$ & \\
\hline & $\begin{array}{l}\text { Curators are } \\
\text { appointed. } \\
\text { Methodological training } \\
\text { may be requested from } \\
\text { the HEE. Employers } \\
\text { may agree to cover the } \\
\text { costs of studies at } \\
\text { HEE. }\end{array}$ & & \\
\hline Stage 5 & \multicolumn{2}{|c|}{$\begin{array}{l}\text { Parties perform their obligations according to the agreements reached. } \\
\text { Prompt reaction to any arising issues is ensured by the systemic dialogue } \\
\text { of the parties. }\end{array}$} & \\
\hline Stage 6 & $\begin{array}{l}\text { Ensure participation of both HEE and partner- } \\
\text { company in the current (for non-graduates) and } \\
\text { final (for graduates) assessment of student's } \\
\text { results. }\end{array}$ & & \\
\hline Stage 7 & $\begin{array}{l}\text { A company may offer a } \\
\text { graduate a permanent } \\
\text { job. }\end{array}$ & $\begin{array}{l}\text { A student may } \\
\text { choose another } \\
\text { company } \\
\text { otherwise is not } \\
\text { indicated in a } \\
\text { trilateral or another } \\
\text { contract, or master's } \\
\text { non-dual program } \\
\text { may also be chosen. }\end{array}$ & \\
\hline
\end{tabular}

Source: developed by the authors based on reports of Ukrainian HEEs listed in the MES Order №1296 
O., Davlikanova, H., Hofstetter. The «Duales Studium» Adaptation as an Innovation in Ukrainian Tertiary Education: Management Aspects and Results.

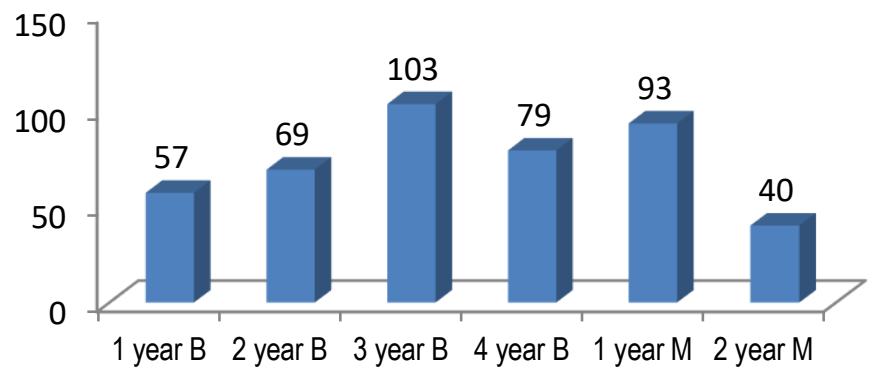

B - Bachelor's Degree; M - Master's Degree. Vertical axis - the number of dual students in 20192020 a.y.

Figure 2. The years and Academic Degrees of DS Proposals Implemented in 2019-2020 a.y.

Source: developed by the authors.

The procedure of student's transfer to the dual form of studies was developed by the HEE in $41 \%$ of cases, by an employer $-10 \%$, together $-40 \%$. Besides, it is not finalized in $9 \%$ of the reported cases. Taking into account the mentioned limitations to the HEE acceptance procedure, the following procedure of transfer to the DS is applied in most cases: Step 1 - applicant passes EIE and enters the HEE; Steps 2 and 3 - a student applies to be transferred to the dual form of studies; a student passes tests/interview at an enterprise (the order of these two steps may change or take place in parallel); Step 4 - trilateral agreement and employment contract are signed. The individual study plan is agreed. Some employers, mostly in the fields of mechanical and electric engineering, demand preliminary studies at their company training centres and only afterwards offer a possibility to pass a test/interview. In case of criteria for applying student assessment, they were elaborated by HEEs in $30 \%$ of cases, by employers $-12 \%$, together $-11 \%$. While, the elaborator was not mentioned in $1 \%$ of the answers, no criteria $-6 \%$ of the cases. Among the criteria, the following were mentioned most often: successful academic performance, self-motivation, independent decision-making, ability to work in a team, basic job-related skills. In $74 \%$ of cases students were transferred to the DS after the first month of the first (autumn) semester, $13 \%$ - after the second month, $7 \%$ - after the third month, $1 \%$ - after the first month of the second (spring) semester, $1 \%$ - before the beginning of the semester, $4 \%$ - students were transferred to the DS right after the acceptance to the HEE. In $80 \%$ of cases, HEEs mentioned they had agreed on an education program with a partner-employer, while the work-based training programs were agreed in all the cases. The time-share models differ a lot and include a «Divided day model» $-10 \%$ of all the cases, a «Divided week model» $31 \%$, a «Divided month model» - 19\%, a «Block model» (divided by months semester) - 37\%. «All» or «other options are possible» was mentioned as an answer in $4 \%$ of the cases. The divided day model included both options of studying in the HEE in the first half of the day and the work-based component in the second part of the day or vice versa. This one suits best for companies located near the HEE. The block model includes curricula built concerning the seasonal works (agriculture); the blocks are not always even, and their duration may vary. "Other options» refers to a case of full-time work with integrated study periods at HEE once every several weeks (Master's program). The DS launch required not only the appointment of persons responsible for strategic cooperation between the HEE and company but those curating a student during dual studies in both study venues. It was mentioned in the Provision on the Organization Studies under the Dual Form. Normative documents in-progress offered for probation in the framework of the experiment. Functions regarding ensuring strategic partnership establishment and resolving current issues are performed by the executives of a DS unit or specifically appointed persons in 
O., Davlikanova, H., Hofstetter. The «Duales Studium» Adaptation as an Innovation in Ukrainian Tertiary Education: Management Aspects and Results

HEEs, as mentioned, and an HR in big and middle businesses or a Director in small businesses. The curators at partner-companies did not receive relevant methodological training in $14 \%$ of cases. In turn, it was provided by the partner HEE in $41 \%$ of the cases. The rest of cases consisting of information showed that it was organized by either employer alone or employer in cooperation with the HEE. Most often, criteria for a curator include 1) profile higher education; 2) experience practical work; 3) professional competences (recognized certificates, publications); 4) ability to teach. Employers are participating in control and assessment of the results of the study phases through, among others, providing feedback during the workbased learning phases and final characteristics at the end of the phase; or participation in both semester control and State Examination Commission's work; etc. Out of the 20 HEEs that have created conditions for DS implementation 19 are state, and only 1 is private. It means that employers do not have to pay for the theoretical component of education in almost all the reported cases, as the state covers it. In those cases, when tuition fee is not covered from the state budget, students covered by themselves, when they study in private HEE or on a contract basis in the state HEEs. However, there were 7 real and 3 potential cases, when employers agreed to cover the cost of studies in an educational establishment. The question (if the cost of the program for the day and dual students should be the same or there should be a different formula) is open for discussion and requires additional research. Strangely, companies do not count the costs of dual studies, which was confirmed by cross-checking research among the employers conducted by the Ukrainian Marketing Association and FES-Ukraine. During the first year, 4 cases of students' refusals to continue dual studies have been reported. The reasons were as follows: family reasons, low salary, academic failure, the complexity of job duties. In one case, a company refused to take a dual student after a probation period because of low academic performance. Among those who graduated in 2020, in 16 cases, students accepted a job offer from their companies. In terms of arising difficulties: 27 responses indicated no issues that hinder the introduction of the duals studies; 22 responses mentioned organizational issues that were solved by negotiations or additional agreements; 13 responses outlined «specific issues» like the quarantine; difficulties in schedule planning depending on students' positions or companies' specific needs in terms of working hours; most IT companies do not have a seal and are not willing to hire students as staff, preferring to subcontract them as self-employed legal entities; the lack of a wide network of cooperation with employers; some companies can hire only 1 person for a particular position (for example, an agronomist), which demands enlarging the number of partner-companies and complicates organization of DS for groups in some majors. The comparative analysis in the national contexts of Germany and Ukraine for DS has shown that it was essential to focus on the main principles and philosophy of DS, rather than attempt to copy all the elements of the system (see Table 2). Following the mentioned above, the findings showed that:

1. Ukraine has an only three-decade history as an independent state with a market economy. The Soviet period has destroyed the concept of the state-private partnership, including in the education sphere.

2. Thus, the notion of private sector investments into human capital is met with scepticism. Employers are cautious when it comes to investing in students, who might afterwards choose a competitor-company or self-employment. In contrast, some employers and their associations insist on state budget benefits for participation in DS.

3. 2019-2020 was the first year of the DS experiment, so the report on the results is the first database of existing dual programs and partner-companies. And even when formed, it will have its peculiarities due to the HEE acceptance procedure.

4. In Ukraine, dual studies is identified by the Law «On Higher Education» as a form of studies along with the institutionalized forms like the internal (day or evening) studies, extramural studies, distance studies and network studies. Thus, there are no separate dual programs (yet). Students having been accepted to the HEE may apply for a transfer to the dual form of education. Suppose they pass 
O., Davlikanova, H., Hofstetter. The «Duales Studium» Adaptation as an Innovation in Ukrainian Tertiary Education: Management Aspects and Results.

successfully an interview or a test at a partner-company. In that case, the work-based component will be integrated into the education plan, their individual study plans and work-based learning plan.

5. The third factor also creates obstacles for the organization of DS for groups. In the most cases, there are no well-established networks with employers, whose efforts could be coordinated to plan the schedule of theory and practice phases for the whole groups, as well as there, are not many companies with capacities to accept groups. Those, it is possible in the future.

6. At the moment the Chambers are not involved in DS under the lack of interest to the subject, on the one hand, and lack of the VET-integrated dual studies model, on the other hand. Their role in some cases is undertaken by professional associations and will soon be somewhat covered by the currently created qualification assessment centres.

Conclusions. Thus, there is no dual system yet, and DS is defined as a form of education, which does not limit it to the need of establishing HEEs specialized in dual studies etc. Ukraine is creating its mechanism of dual studies (see Table 3). The author's questionnaire survey on the results of the first year of the experiment of the MES on the introduction of the dual studies showed that Ukraine could successfully adapt German best practices if a flexible approach is applied. Though some significant elements of the dual studies as a system are missing, the launch may be considered effective based on the cases of in-depth cooperation of HEEs and companies that meet the philosophy of dual studies and the national legislative requirements to the DS.

Responses regarding the motives of DS introduction indicate that all the stakeholders understand the need in the development of the mechanisms that: brings education and real economic sector closer; allows providing national economy with a highly qualified and well-educated workforce capable of innovations in the time of fast-developing technologies; shifts to the knowledge-based economy. The quarantine caused by the COVID-19, which effected the experiment, stimulated the on-line (distant) learning and mixed forms of studies. It may simplify compiling schedules for dual students, but may also demand changes to the definition provided in the Law on Higher Education that underlines significance of the daytime academic component as part of the DS.

The growing quote of distant learning in Germany shows the prominence of blended learning which improves the time-compatibility of studies and job, and furthermore the necessary didactic shift from teaching to learning (BIBB, 2016). At this stage, due to such factors as the introduction of the DS on the initiative of the international organization, the MES, mostly educational establishments and only a few big businesses, lack of tradition of employer-HEE cooperation and unstable economic and political situation, HEEs have become the main promoters of the DS. However, a massive information campaign is needed among employers to motivate them to take a pro-active role in this regard. Establishment of wide cooperation networks and creation of relevant on-line databases should become a priority for the next stage of the experiment, as well as the finalization of the normative framework. For avoiding misinterpretations or manipulations among involved actors, it is advisable to invest efforts into the elaboration of methodological and information materials for all stakeholders. More attention should be paid to the mechanisms of assuring connection of theory and practice, as well as division of the ECTS credits and formation of the schedule. For most employers, it comes as a surprise that $70 \%$ of the dual education costs are covered by the income created by the dual-students (BIBB, 2020).

It is recommended to organize a separate study of dual students' experiences. During the first year of the experiment, $1 / 3$ of all the students involved were female, perhaps, the gender aspect of DS introduction shall be studied additionally to prevent the possible influence of factors causing gender disparities. The results support the suggestion that the national context and the manifold requirements of students and employers demand a respectable variety of Dual Study models. Even in the motherland of dual education, the diversity enlarged considerably due to the growing and differentiating demand (BiBB, 2020). Still, as 
O., Davlikanova, H., Hofstetter. The «Duales Studium» Adaptation as an Innovation in Ukrainian Tertiary Education: Management Aspects and Results

of now, it seems like the VET-integrated model will not be in demand, while the practice-integrated model would be used the most.

Table 4. Models of Dual Studies in Germany

\begin{tabular}{|c|c|c|}
\hline & Model & Format \\
\hline \multirow{3}{*}{ Initial Education } & integrated VET & VET qualification + Bachelor Degree \\
\cline { 2 - 3 } & integrated in-company/vocational training & Bachelor Degree + in-company \\
(practice-integrated) & training program \\
\hline \multirow{3}{*}{$\begin{array}{c}\text { Continuing } \\
\text { Education }\end{array}$} & in parallel with professional occupation \\
(practice-integrated) & $\begin{array}{c}\text { Work + higher education } \\
\text { (Master/Bachelor) }\end{array}$ \\
\cline { 2 - 3 } & integrated in-company/vocational training \\
(practice-integrated) & $\begin{array}{c}\text { Work, higher education } \\
\text { (Master/Bachelor) }\end{array}$ \\
\hline
\end{tabular}

Source: developed by the authors based on BiBB-report (2020).

The results of our survey and the experiences in this country and abroad with dual education require special attention from higher educational establishments, employers and their associations, HR specialists, students, the Ministry of Education and Science of Ukraine and other profile ministries, Chambers of Trade and Commerce, self-government bodies responsible for regional economic development and education, and other interested parties. The present results are the milestone for the introduction of dual studies in Ukraine as a prerequisite for youth unemployment rate drop and national economic development rooted in human capital investments.

Author Contributions: conceptualization, methodology, writing-review and editing O. D., H. H.

Acknowledgements. The author is grateful to all the enthusiasts, who invested their time and effort into promoting the DS adaptation idea; the Ministry of Education and Science of Ukraine for support and establishing conditions for the experiment; those Ukrainian HEEs that provided the information for this study.

\section{References}

BiBB. (2012). Memorandum on Cooperation in Vocational Education and Training in Europe. Vocational Education and Training in Europe - Perspectives for the Young Generation. Retrieved from https://www.bibb.de/dokumente/pdf/memorandumvocational education and training 2012.pdf

Braun, G., \& Schlüter, A. (2018). Erfolgsmodell Duales Studium. Leiffaden für Unternehmen. Retrieved from https://www.arbeitgeber.de/www/arbeitgeber.nsf/res/Duales-Studium.pdf/Sfile/Duales-Studium.pdf

Bundesinstitut für Berufsbildung (2016). Verzahnung beruflicher und akademischer Bildung. Retrieved from http://www.bibb.de/veroeffentlichungen

Bundesinstitut für Berufsbildung (2017). Empfehlung des Hauptausschusses des Bundesinstituts für Berufsbildung vom 21. Juni 2017 zum dualen Studium. Retrieved from https://www.bibb.de/dokumente/pdf/HA169.pdf

Bundesinstitut für Berufsbildung (2020). Duales Studium in Zahlen 2019. Retrieved from http://www. bibb.de/veroeffentlichungen Bundesinstitut für Berufsbildung (2020a): BIBB-report Heft 1: Ausbildung in Deutschland, Investition gegen Fachkraeftemangel, Mai 2020. Retrieved from http://www.bibb.de/veroeffentlichungen

Del Carpio, X., Kupets, O., Muller, N., \& Olefir, A. (2017). Skills for a modern Ukraine. The World Bank. [Google Scholar] EU Benchmarks. Education and Training 2020. (2020). Eurostat. Retrieved from https://ec.europa.eu/eurostat/web/education-andtraining/eu-benchmarks

Dźwigoł, H., \& Dźwigoł-Barosz, M. (2018). Scientific Research Methodology in Management Sciences. Financial and Credit Activity: Problems of Theory and Practice, 2(25), 242-237. [CrossRef] [Google Scholar]

Dzwigol, H., Dzwigol-Barosz, M., Miskiewicz, R., \& Kwilinski, A. (2020). Manager Competency Assessment Model in the Conditions of Industry 4.0. Entrepreneurship and Sustainability Issues, 7(4), 2630-2644. [CrossRef] [Google Scholar]

European Commission. (2016). 2016 European Semester: Country Reports and Communication. Retrieved from https://ec.europa.eu/info/publications/2016-european-semester-country-reports en

Eurostat. (2018). Tertiary educational attainment by sex, age group 30-34. Retrieved from https://ec.europa.eu/eurostat/tgm/refreshTableAction.do?tab=table\&plugin=1\&pcode=t2020 41\&language=en 
O., Davlikanova, H., Hofstetter. The «Duales Studium» Adaptation as an Innovation in Ukrainian Tertiary Education: Management Aspects and Results.

Graf, L., Powell, J. J., Fortwengel, J., \& Bernhard, N. (2014). Dual study programmes in global context: Internationalization in Germany and transfer to Brazil, France, Qatar, Mexico and the US. [Google Scholar]

Gresham J. (2019). Study of the Sphere of Education in Ukraine. World Bank. Retrieved from http://documents.worldbank.org/curated/en/790931568661644788/pdf/Overview.pdf

Ivanova, V. V. (2011). Knowledge-based economy and knowledge economy: the adequacy of using categories. The mechanism of regulation of the economy, (3), 47-54. Retrieved from http://mer.fem.sumdu.edu.ua/content/acticles/issue 14/V V IvanovaKnowledge based economy and knowledge economy ade quacy_of_categories_usage.pdf.

Kamata, H. (2016). A Segmentation Analysis of Japanese Spa Tourists. Journal of Tourism \& Services, 7(12). [Google Scholar] Kuznets, S. (1971). Modern economic growth: findings and reflections. Retrieved from https://www.nobelprize.org/prizes/economic-sciences/1971/kuznets/lecture/

Kuznets, S. (2013). Economic growth of nations: Total output and production structure. Harvard University Press. [Google Scholar]

Kuznyetsova A. Ya., Zherebylo I. V., Klipkova O. I., Kozmuk N. I. Creation of the value of national enterprises with the help of the innovation centers in the cluster formations. Financial and credit activities: problems of theory and practice. 2019. Vol. 2. No 29 . P. 391-402. [Google Scholarl [CrossRef]

Kwilinski, A., Vyshnevskyi, O., \& Dzwigol, H. (2020). Digitalization of the EU Economies and People at Risk of Poverty or Social Exclusion. Journal of Risk and Financial Management, 13(7), 142. [Google Scholar] [CrossRef]

OECD (2014). Education at a Glance 2014: OECD Indicators. [CrossRef]

Ranasinghe, R. (2019). Antecedents of Job Performance of Tourism Graduates: Evidence from State University-Graduated Employees in Sri Lanka. Journal of Tourism and Services, 10(18), 16-34 [CrossRef] [Google Scholar]

Romer, P. M. (1990). Endogenous technological change. Journal of political Economy, 98(5, Part 2), S71-S102. [Google Scholar]

Schultz, T. W. (1960). Capital formation by education. Journal of political economy, 68(6), 571-583. [Google Scholar]

The Ilko Kucheriv Democratic Initiatives Foundation. (2015). Higher Education in Ukraine: Students' Oppinion Survey. Retrieved from http://dif.org.ua/article/vishcha-osvita-v-ukraini-gromadska-dumka-studentiv

The Law of Ukraine "On Higher Education" № 392-IX as of 18.12.2019. Retrieved from https://zakon.rada.gov.ua/laws/show/1556-18

The Strategy of the Higher Education Reformation in Ukraine till 2020. (2016). Retrieved from https://mon.gov.ua/storage/app/media/gromadske-obgovorennya/2016/18-strategiva-reformuvannya-vishhoi-osviti-20.doc

Toffler, A. (1990). Knowledge, Wealth, and Violence in the 21st Century. Barcelona: Plaza \& Janes. [Google Scholar]

Vovchak O. D., Senyshch P. M., \& Melnyk T. V. «Purging» Of The Banking System: Impacton The Key Performance Indicators Of Banks. Financial and credit activities: problems of theory and practice. 2019. T. 1. № 28. C. 16-25. [Google Scholar] [CrossRef]

Олена Давліканова, координатора проектів Представництва Фонду ім..Фрідріха Еберта в Україні, Україна Хельмут Хофштеттер, професор, Берлінська вища школи економіки та права, Німеччина

Інноваційні підходи у вищій освіті України: адаптація німецьких філософії та моделей організації дуальної вищої освіти до національного контексту

Ця стаття узагальнює досвід першого року експерименту Міністерства освіти і науки України щодо впровадження дуальної форми навчання у закладах вищої освіти. Систематизація літературних джерел засвідчила важливість впровадження інноваційних підходів для вирішення проблеми розриву між потребами ринку праці та змістом освіти, а також рівнем кваліфікацій, отриманих здобувачами протягом навчання у закладах вищої освіти, особливо в період переходу до економіки знань та підвищення попиту на спеціалістів із вищою освітою. Актуальність пошуку дієвих моделей організації здобуття освіти за дуальною формою в національному контексті продиктовано давно існуючою потребою економіки у висококваліфікованих кадрах, запитом на необхідність доопрацювання існуючої законодавчонормативної бази та потребою забезпечення методичного супроводу експерименту МОНУ. Основною метою дослідження є визначення специфіки організації дуальної форми навчання з урахуванням особливостей національного законодавства, системи освіти, спроможностей роботодавців та традииій співпраці між роботодавиями та закладами вищої освіти. У статті представлено результати кабінетного дослідження німецької системи дуальної вищої освіти у порівнянні до емпіричного аналізу результатів опитування 27 закладів вищої освіти. Опитування проводилось з квітня по липень 2019 року. Отримані результати свідчать відсутність значної кількості елементів німецької системи, зокрема, мереж кооперації, відповідних баз даних, достатнього об'єму методичних рекомендацій, традицій соціального партнерства в освітній ссері в умовах ринкових відносин. При иьому дуальна форма може застосовуватися до широкого кола спеціальностей на рівні здобуття ступеня бакалавра та магістра, а також може бути організована за різними моделями. Дослідження емпірично підтверджує та теоретично доводить, що дуальна форма навчання є затребуваною, можливою для реалізації та перспективною. Отримані результати можуть бути корисними для закладів вищої освіти, роботодавців та їх об'єднань, здобувачів освіти, що бажають впроваджувати чи здобувати освіту за дуальною формою, а також Міністерству освіти і науки України та іншим профрільним міністерствам. 
O., Davlikanova, H., Hofstetter. The «Duales Studium» Adaptation as an Innovation in Ukrainian Tertiary Education: Management Aspects and Results

Ключові слова: дуальна вища освіта, дуальна форма здобуття освіти, моделі організації здобуття освіти за дуальною формою, Duales Studium, роботодавці, заклади вищої освіти, людський капітал, Міністерство освіти і науки України, пілотний проєкт, здобувачі освіти, вища освіта.

Manuscript received: 31.01.2020

(C) The author(s) 2020. This article is published with open access at Sumy State University 